\title{
Alessia Zubani. "La Trasmissione del modello regale iranico in epoca islamica: il caso del Testamento di Ardašīr"
}

\section{Samra Azarnouche}

\author{
(2) OpenEdition \\ Journals \\ Édition électronique \\ URL : http://journals.openedition.org/abstractairanica/47817 \\ DOI : $10.4000 /$ abstractairanica. 47817 \\ ISBN : 1961-960X \\ ISSN : 1961-960X \\ Éditeur : \\ CNRS (UMR 7528 Mondes iraniens et indiens), Éditions de l'IFRI
}

\section{Référence électronique}

Samra Azarnouche, «Alessia Zubani. "La Trasmissione del modello regale iranico in epoca islamica: il caso del Testamento di Ardašîr" », Abstracta Iranica [En ligne], Volume 40-41 | 2019, document 1, mis en ligne le 15 juillet 2019, consulté le 27 avril 2021. URL : http://journals.openedition.org/ abstractairanica/47817 ; DOI : https://doi.org/10.4000/abstractairanica.47817

Ce document a été généré automatiquement le 27 avril 2021.

Tous droits réservés 


\section{Alessia Zubani. "La Trasmissione del modello regale iranico in epoca islamica: il caso del Testamento di Ardašīr"}

Samra Azarnouche

\section{RÉFÉRENCE}

Alessia Zubani. "La Trasmissione del modello regale iranico in epoca islamica: il caso del Testamento di Ardašǐ" in F. Calzolaio, E. Petrocchi, M. Valisano, A. Zubani (eds.). In limine. Esplorazioni attorno all'idea di confine. Venezia : Edizioni Ca' Foscari, 2017, p. 69-90

Cet article revient sur la question de la transmission et l'usage de concepts politicoreligieux iraniens à travers l'époque islamique classique, en s'appuyant sur le «testament d'Ardašīr », sorte de Miroir de princes connu seulement dans une version arabe, mais qui a du circuler oralement sous des formes diverses. Deux aspects sont mis en lumière : la notion de transmission aux successeurs légitimes d'Ardašīr et celle de l'union sororale entre la royauté et la religion, cette dernière étant éclairée par des parallèles dans la littérature zoroastrienne tardive. 


\section{AUTEURS}

\section{SAMRA AZARNOUCHE}

EPHE, Mondes iranien et indien, Paris 